\title{
To replace the Friendly Society Act 25 of 1956 with the proposed Insurance Bill 2015; a new perspective on society members' benefits in exchange for a premium
}

\section{CG Kilian}

MA LLM LLD

Research Fellow, Centre for Comparative Corporate Governance, Deakin University

Research Fellow, Department of Mercantile Law, University of the Free State

\section{E Snyman Van-Deventer}

LLM LLM LLD

Professor of Law, Department of Mercantile Law, University of the Free State

\section{OPSOMMING}

Om die Wet op Onderlingehulpverenigings 25 van 1956 te vervang met die voorgestelde Versekeringskonsepwet 2015: 'n nuwe perspektief oor hulpverenigingslede se voordele in ruil vir ' $n$ premie

Die Wet op Onderlinge Hulpverenigings is 'n besondere stuk wetgewing wat om een of ander rede intense akademiese bespreking oor 60 jaar vrygespring het. Onderlingehulpverenigings is 'n vorm van versekering wat nie tipies as kort- of langtermynversekering in Wet 25 van 1956 bespreek word nie. Om hierdie rede is dit moontlik dat 'n lid se voordeel verdere regsbepalings het volgens die kort- of langtermynwetgewing in Suid-Afrika. Dit is ook moontlik dat die voordeel geensins deel vorm van die kort- of langtermynwetgewing nie maar eerder 'n sui generis-vorm van versekering is, naamlik die stokvel as besigheidsvorm in Suid-Afrika. Met die inwerkingtreding van die voorgestelde Versekeringskonsepwet 2015 gaan onderlingehulpverenigings nie meer as besigheidsvorm voortbestaan nie, maar daar heers onduidelikheid oor die stokvel as besigheidsvorm in die toekoms. Die nuwe wet gaan duidelikheid bring oor presies hoe onderlingehulpverenigings as mikroversekering in die kort- en langtermynwetgewings getipeer gaan word deur middel van wysigings aan beide wetgewings. Alhoewel die wysigings nuut mag voorkom, bevat die Wet op Onderlinge Hulpverenigings reeds bestaande begrippe wat nou ander betekenisse kry volgens die Versekeringskonsepwet. 'n Praktiese voorbeeld is die nuwe term om selstruktuurversekering te omskryf wat voorheen bekend gestaan het as 'n sentrale onderlingehulpverenigingsstruktuur - geen akademiese bevestiging kon gevind word nie maar die oorvleulende eienskappe tussen die twee terme dui op een en dieselfde konsep. Om hierdie rede verskaf sentrale onderlingehulpverenigings duidelike praktiese voorbeelde oor hoe formules omskryf kan word om eensgesindheid te bring by die verdeling van winste in selstruktuurversekering. Buiten laasgenoemde word daar ook gelet op die nuwe ledevoordele van mikroversekeraars volgens kort- of langtermyn- 
versekering en hoe dit tans vergelyk met bestaande ledevoordele van onderlingehulpverenigings.

\section{Introduction}

The Friendly Society Act was introduced in 1956 as a method to introduce a new business entity into the South African corporate landscape yet, sixty years later, little has been published concerning it by South African law academics or the judiciary. In fact, our research for this article into published case law matters and academic articles revealed just five cases and three articles in law journals that related to friendly societies in one way or the other since 1956; moreover, these articles referred just briefly to friendly societies in South Africa. ${ }^{1}$ On the other hand the Friendly Society Act 25 of 1956 has been amended by twentyfive pieces of legislation over a sixty year time period. Although society benefits are regulated in Sections 2, 18 and 19 of the Act, those benefits have not been classified as either short term insurance or long term

1 Oranje Benefit Society v Central Merchant Bank Ltd 1976 (4) SA 659 (A) deals with ultra vires contracts entered into by society officials/directors with a third party. The word director does not appear in Section 1 of the Friendly Society Act 25 of 1956. The Act only defines an officer, which includes any person/member appointed to manage the affairs of the society; Ex Parte Steenkamp 1996 (3) SA 822 (W) deals with the legal requirements for voluntary sequestration of a natural person's estate, while a policy issued by a friendly society is excluded from the estate to be sequestrated; Family Benefit Friendly Society v Commissioner for Inland Revenue 1995 (4) SA 120 (T) where a society has not gone into business but asks the court for an opinion on a tax matter should the society decide to conduct business. Mouton v Die Mynwerkersunie 1977 (1) SA 119 (A) where a person approached a society for a loan to develop property. The society could not grant the loan but nevertheless used its creditworthiness to assist the person in obtaining cash. The society's constitution should permit loans or grant the circumstances under which loans could be granted; Volkskas Beleggingskorporasie v Oranje Benefit Society 1978 (1) SA 45 (A) where any loan granted ultra vires allows the society to claim back any money paid plus interest; Central Merchant Bank Ltd v Oranje Benefit Society 1975 (4) SA $588(C)$ refers also to ultra vires loans as decided in the previous matter; See in general Swart \& Lawack-Davids 'Understanding the South African Financial Markets: An Overview of the Regulators' 2010 Obiter 619-637; Mpedi \& Millard 'Bridging the GAP: The Role of Micro-Insurance in a Comprehensive Social-Protection System in South Africa' 2010 Obiter 497 517; D Millard 'For Whom the Bell Tolls ... Interplay between Law of Delict and Social Security Law in Three Modern Compensation Systems' 2010 TSAR 532-557; See in general Von Nessen 'Financial Services Reform: What can be Learned from the Australian Experience?' 2006 TSAR 64-82. While this article is interesting, nevertheless, the requirements of product disclosure and or disclosure of financial services rendered are not applicable to friendly societies in terms of the Friendly Society Act 1956; See in general as to the first friendly society in South Africa as a 'medical scheme' in McLeod 'Mutuality and Solidarity in Healthcare in South Africa' 2005 South African Actuarial Journal 135-167. 
insurance benefits in the Act. ${ }^{2}$ To understand whether a society benefit is indeed a short term insurance benefit or a long term insurance benefit, reference must be made to the Short Term Insurance Act or the Long Term Insurance $\mathrm{Act}^{3}$. In any event, the amount or the maximum amount of benefits payable to a society beneficiary or member is limited to R7500. ${ }^{4}$ Besides the above, Section 47 of the Friendly Society Act makes provision to issue regulations relevant to the payment of a society's benefits, the maximum amount of investments to be made on behalf of the society and or actuarial scrutiny of benefits paid by the society and so forth. In total, twenty-nine regulations have been issued since $1962 .{ }^{5}$ The financial statements of the friendly societies are required to disclose general and statistical information pertaining to claim benefits paid to society members in the aggregate as a method to calculate the loss ratio per product; for example, medical-, sick pay-, death-, funeral benefits and or other benefits paid, expressed as a percentage of the total premium received. ${ }^{6}$ It is clear that this regulatory template for financial statements is only an example of the different types of benefits payable in terms of sections 2, 18 and 19 of the Act and of how low or high their individual loss ratios may be in comparison to one another. ${ }^{7}$

In terms of the Insurance Bill, the terminology associated with friendly societies will disappear completely; for example, the terms 'central society' and 'friendly society'. The new Bill introduces new terminologies pertaining to micro insurance; for example, cell structure insurance and different forms/types of micro insurance benefits (some benefits are not presently found in the in Act of 1956, i.e. the credit life insurance benefit) and the cell structure insurance practices will be compared with the practices of the central society as regulated in the present Act of $1956 .{ }^{8}$

2 Section 2 deals with general society benefits or products, for example, funeral costs etcetera. Section 18 deals with the payment of members' benefits to members' beneficiaries or nominees and section 19 deals with benefit payments of children under the age of 14 years, who have died.

3 See for example the Short Term Insurance Act 53 of 1998 section 7(2)b.

4 The regulation of the maximum amount of benefits payable in the Short Term Insurance Act is based on section 7(2)b of the Act and authorises the Minister of Finance to determine the maximum amount of benefits payable to society members. For example, the Minister signed or authorised a notice on the 1 March 2008 which limits the maximum amount of money payable to society members to R7500.

5 Originally published in Government Gazette 1409 of 1966/03/25 as various Government Gazette amendments in Government Gazette 9437 of 1984/ 09/28, Government Gazette 12079 of 1989/09/1, Government Gazette 13536 of 1991/09/27, Government Gazette 14572 of 1993/02/12, Government Gazette 20057 of 1999/05/14 and Government Gazette 28627 of 2006/03/17.

6 Government Gazette 1409 of 1966/03/25, for example, indicates the preferred disclosure of different benefits paid in the financial statements.

7 For example, section 7 which was published in Government Gazette 1409 of 1966/03/25 requires total sick pay benefits paid. Section 1 requires income or gross premium received. It is thus possible to specify gross premium in the aggregate or be product specific in relation to claims paid out to members.

8 Section 1 of the Insurance Bill defines a cell structure, etcetera. 
Micro insurance businesses will be able to insure life insurance products up to a maximum of R50 000 and R100 000 for short term insurance products. ${ }^{9}$ This maximum monetary policy benefit will assist micro insurers to compete more aggressively with other insurance companies by selling a greater variety of micro- insurance products compared to the Act of 1956. In addition to the latter, this article refers briefly to stokvel benefits, the maximum amount payable by a stokvel and how the Insurance Bill will regulate stokvel benefits in the future; i.e., whether it will be a requirement to register any form of stokvel business. ${ }^{10}$

Furthermore, this article uses practical examples to illustrate cell structures (or business schemes) since no law literature in South Africa exists on this topic. ${ }^{11}$ Although the latter statement sounds technical, in this article simple examples are used to explain the relevance of central societies in the financial industry and whether central societies as business schemes, will still be able to continue as such in the future. In the literature, the calculation of profits relevant to business schemes is very scanty. For this reason, the researchers used examples employed by insurers in their binder agreements to calculate profits. ${ }^{12}$ Besides the latter, the researchers were unable to find any law articles in reference to the profit sharing formulae examples as discussed in this article.

\section{What is a Friendly Society?}

The definition in terms of the Act of 1956 seems simple and uncomplicated in its application to regulate entities as friendly societies. Section 1 of the Act defines a friendly society as follows:

(a) Any association of persons established for any of the objects specified in Section 2 or

(b) Any business carried on under a scheme or arrangement instituted for any of those objects, and includes any central society referred to in Section 39, whether or not it is liable to provide any benefits mentioned in Section 2 and or any central society, association or business aforesaid which is or may become liable for any such benefits, whether or not it continues to admit or to collect contributions from members.

9 See www.treasury.gov.za/publications/other/MicroinsuranceRegulatoryFram ework/Policy \% 20Document \% 20Micro \% 20Insurance.pdf (accessed 201601-01).

10 Van der Merwe 'Die Stokvel 'n Ondernemingsregtelike Studie' 1996 Transactions of the Centre for Business Law 4.

11 See Section 1 of the Insurance Bill for various definitions to cell structure etcetera; See Friendly Society Act section 39, which defines a central society.

12 The researchers signed a confidentiality agreement and cannot disclose the names of the insurers consulted. The formulae employed by different insurers vary from one insurer to another. Mostly the insurers will rely on a contractual clause to allow them to deduct any discretionary costs associated with the business scheme. 
A company is also an association of persons, but the court in Ex Parte Liquidators Royal Oak, Ancient Order of Foresters Friendly Society held that a friendly society is an unregistered company. ${ }^{13}$ Although this case was decided in 1941, it is currently equally applicable since a friendly society is incorporated in terms of the Friendly Society Act 1956. Although such a society has often been referred to as a non-profit organisation, it is not similar to a Section 21 company of the Companies Act 1973 or a Section 10 non-profit company in terms of the Companies Act 2008. ${ }^{14}$ The latter two companies participate in charity and or any other public benefit. ${ }^{15}$ The same applies to friendly societies; however, the difference is simply that a friendly society's conduct is the rendering of insurance business; for example, medical assistance benefits or accidental death benefits as regulated in section 2 of the Act. ${ }^{16}$ For this reason a society's income or premium income is distributable to its members as an undertaking to provide policy benefits as regulated in section 2 of the Act, whereas non-profit organisations/companies are not allowed to distribute their income to any of their members. The members of a non-profit organisation are in fact the board of directors and the latter may receive remuneration as employees of the organisation or company. ${ }^{17}$ It is at the discretion of the board of directors to decide to help a certain section of the public or a member of the public for charity purposes. The features of Section 1 quoted above are individually discussed in the following paragraphs.

\section{Any Association of Persons}

It is clear from the information above that if an association of persons provides any of the society's benefits or objects in Section 2, this

131941 CPD 178.

14 Lambert 'Maintaining a British Way of Life: English-Speaking South Africa's Patriotic, Cultural and Charitable Associations' 2009 Historia 55-76. A nonprofit company is registered in terms of the Companies Act 71 of 2008.

15 For example, to pay funeral costs to the public where a member of the public is unable to pay these costs. A society may sell a policy/benefit to pay for funeral costs when the member of the society dies. The date of death is uncertain; however, the member contributes to the society on a monthly basis to accept a claim submitted to the society in the event of death of a member; See in general Re Bucks Constabulary Widows' and Orphans Fund Friendly Society v Holdsworth [1979] 1 All ER 623.

16 See in general Trustees of the National Deposit Friendly Society $v$ Skegness Urban District Council [1958] 2 All ER 601. The court refers briefly to the insurance business of a friendly society. Unlike insurance companies, a friendly society cannot pay any dividends to its members, making the society a non-profit business entity. The non-profit business is not similar to non-profit companies registered to complete a public benefit or charitable cause; Verhoef “"Wie Moet Sorg?” Gesondheidsbeleid en Mediese Fondse in Suid-Afrika in Vergelykende Perspektief 1900-1970’ 2007 Historia 19-49.

17 See Companies Act 2008, schedule 1, item 1(1); Verhoef 'Savings and Survival in a Modern African Economy: Informal Savings Organizations and Poor People in South Africa' 2001 Historia 51 9-542. 
association should register as a friendly society. ${ }^{18}$ However, Section 3 of the Act excludes the following entities as friendly societies: ${ }^{19}$

(a) A fund created in terms of the Labour Relations Act 1956 and or

(b) The aggregate income value of the society does not exceed a R100 000 per annum and the entity with less income shall comply with any regulation that may be made in relation to it.

Point $\mathrm{b}$ above is relevant to our discussion: it simply states that if an entity or a society receives income less than R100 000 per annum, such an entity or society is not obliged to register the association of persons as a friendly society in terms of the Act. The consequences of such an entity are far reaching. For example, as long as the entity earns less than R100 000 income per annum, it can pay policy benefits to its members in excess of R7500 and can issue benefits other than those listed in Section 2 of the Act. ${ }^{20}$ Section 2 benefits or policy benefits are discussed in detail in paragraph 23 . In addition, the friendly society is required to register society or member rules (the society's constitution) relevant to members' rights and duties. Therefore, if the income is less than the statutory requirement, it is possible to have an entity that does not have member rules. The latter provision is regulated in Section 3(2)(a) of the Act and reads as follows:

If the registrar is satisfied that the aggregate value of the income likely to be received by a friendly society which is at the commencement of the Friendly Societies Amendment Act 1988 registered under this Act, will not in general exceed during any year an amount of R100 000, he may by notice in writing addressed to that society, and on such conditions as may be specified in that notice, exempt that society from operation of all or any of the provisions of this Act.

Considering the above, it is clear that the registrar of societies can nevertheless require an entity to register as a friendly society in terms of Section 5 of the Act even if the income per annum is less than R100 $000 .^{21}$ Or the registrar may exempt the entity from all the requirements in Section 5. Part of the registration requirements deals with the provisional registration of an entity as a friendly society for a maximum period of 5 years, after which the society must apply for final registration as a friendly society. The requirements for final registration, which appear in Section 5(4), in brief are the following: the rules or constitution of the society should not be inconsistent with the Act; ${ }^{22}$ the rules should

18 See in general Sissons 'Friendly Societies' 1977 Victoria University Wellington Law Review 59-75.

19 See in general Sissons supra at 64.

20 See in general Sissons supra at 67 and 68. In 1909 the maximum benefits payable to society members in New Zealand were $\$ 3100$ per annum.

21 See in general Sissons supra at 70. Here the author distinguishes between state welfare payable and society benefits and it seems that there were no thresholds in minimum income required to register a society. Nevertheless, a decline in societies was noticed in New Zealand; See www.news24.com/ SouthAfrica/Local/Kouga-Express/mpendulo-members-visit-jeffreys-baywind-farm-20160504 (accessed 2016-04-19). 
be financially sound, ${ }^{23}$ the business or society benefits provided should not be undesirable; ${ }^{24}$ the society should be in a financially sound condition $^{25}$ and the rules of the society should not be unduly inequitable as between different society members. ${ }^{26}$ If the latter requirements are met, the registrar will register the society as final and it shall cease to operate provisionally.

\section{Stokvels}

Although a friendly society is executing the business of insurance, a society is not defined as an insurer in either the Long Term Insurance Act 52 of 1998 or Short Term Insurance Act 53 of 1998. This is in fact strange, since Section 3(2)b of Act 1956 refers to a society as an entity that operates exclusively by means of selling policies of insurance similar to a short term or long term insurer. In addition the society collects a monthly premium in exchange for Section 2 policy benefits. However, if it earns an income of less than R100 000 per annum the society may continue with the business of insurance since it is exempt from the registration requirements relevant to friendly societies. ${ }^{27}$ This society can be interpreted or be classified as a stokvel. ${ }^{28}$ The term stokvel or stockfel /stockfair commonly refers to an association of persons pooling their money together to help one another in times of risk or need. ${ }^{29}$ To help one another or to receive stokvel benefits is based on a rotation principle relevant to the association of persons. For example, a funeral (burial society) stokvel is an association of persons pooling their money together to pay benefits on a rotational basis as and when individual stokvel members die. The benefit is paid in cash and is unlimited in its quantum, while the types of benefits are also not regulated in Section 2 of the Act $1956 .{ }^{30}$ On the other hand, it is possible for the members to agree voluntarily on a set of rules or a constitution to regulate stokvel management decisions, the appointment of stokvel managers and or to regulate the maximum amount of money payable to a person when an uncertain event occurs, for example death or funeral costs. ${ }^{31}$ Besides the latter, if a stokvel earns more than R100 000 per annum, there is no need to comply with the requirements to register the stokvel as a society if the following criteria are met in terms of Section 2(2) of the Friendly Society Act. Section 2(2) reads:

No association or business shall be regarded as a friendly society:

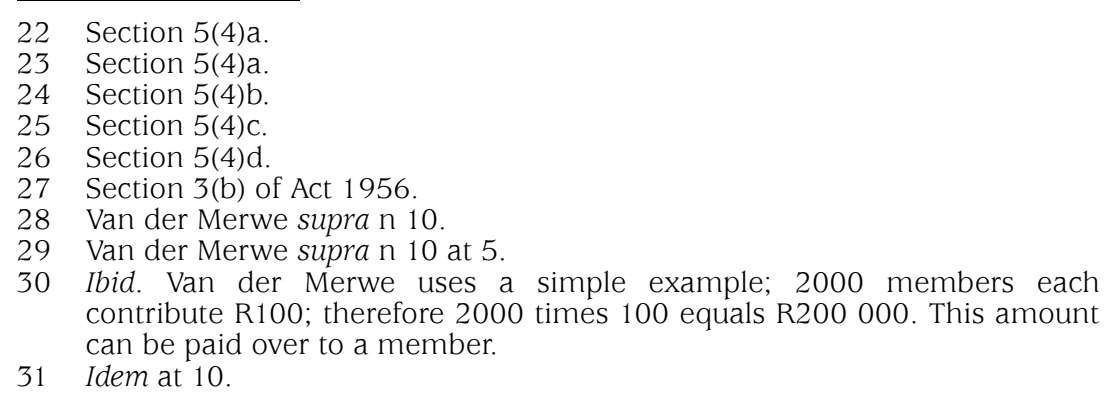


(a) If none of the persons entitled to the benefits specified in Section 2 subSection 1 contributes to such association or business or ${ }^{32}$

(b) If any of the its activities fall within the objects of a pension fund organization as set out in paragraph (a) or (b) of the definition of 'pension fund organization' in Section 1 of the Pension Funds Act or ${ }^{33}$

(c) If in terms of its rules each member is entitled at all times to withdraw the full amount of his contributions, subject to such notice as may be prescribed in its rules or ${ }^{34}$

(d) If the benefits mentioned in Section 2 sub-Section 1 are provided exclusively by way of loans which in terms of its rules must be repaid. ${ }^{35}$

Therefore, if a stokvel allows a member to withdraw his or her monthly contributions and it earns more than R100 000 per annum, it is exempt from the registration requirements due to Section 2(3). Point d) above is also interesting and refers to a credit stokvel, which is also exempt from society registration requirements. ${ }^{36}$ On the other hand, a stokvel that is exempt from the Friendly Society Act is not limited by the maximum amount of R7500, as in the case with friendly societies. ${ }^{37}$

\section{Any Business Carried on Under a Scheme}

\section{Background and Technical Explanation}

Understanding a friendly society which carries on its business under a scheme can be a complicated endeavour. The Act refers to a central society as a scheme, immediately posing the question of what types of entities are considered central societies. To understand this sub-Section clearly it is important to refer to Section 1 of the Insurance Bill. Section 1 introduces new terminology into the insurance industry; for example, cell captive and cell structure. Each of these terminologies will be discussed separately to illustrate the financial purpose of a central society and its benefits. Section 1 of the Bill reads:

(a) Cell captive insurer - means an insurer that only conducts insurance business through a cell structure.

(b) Cell structure - means an arrangement under which an entity (cell owner)

(c) Holds an equity participation in a specific class or type of shares of an insurer...

(d) Is entitled to a share of the profits and liable for a share of the losses ... losses generated by the insurance business ...

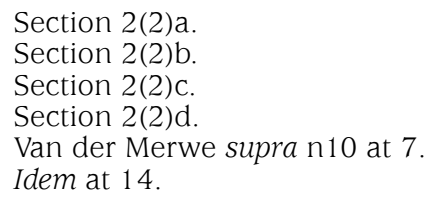


(e) Places insurance business with the insurer referred to in paragraph (a) which business is ring-fenced on a going concern basis from the other insurance business of that insurer.

Neither the Short Term Insurance Act nor the Long Term Insurance Act refers to a cell captive or cell structure of the insurer's business. Some insurers in South Africa employ the concept 'cell structure' without any legislative guidance in the present since the Bill will only become law early in 2017. The 'cell structure' is the result of new terminology introduced in 2011 to allow business entities to share in the profits of the insurer and to act as if they are the insurer without applying for an insurer's licence in South Africa; therefore, the company operates as a 'cell' within the insurer's business. ${ }^{38}$ This new terminology, for example, refers to an insurance underwriting manager participating in or sharing in the profits of the insurer. ${ }^{39}$ An insurance underwriting manager is not a registered insurer but is allowed to act as if it is a registered insurer if the insurer and the underwriting manager have entered into a binder contract. ${ }^{40}$ In terms of this contract, the underwriting manager may bind the insurer to any type of insurance contract entered into with a policy holder without informing the insurer beforehand of the conclusion of a policy contract with a policy holder. ${ }^{41}$ In terms of the binder contract, the underwriting manager is entitled to calculate its own premiums in exchange for risk, to settle claims, to reject claims and the like as if it is the insurer who had calculated the premiums, settled the claims and so forth. ${ }^{42}$ The underwriting manager is therefore entitled to share in the insurance profits of the insurer based on its ability or performance to conduct/run a profitable business of insurance. ${ }^{43}$ The binder contract can stipulate a formula as to how to calculate the profits between the insurer and the underwriting manager. ${ }^{44}$ A simple, practical formula is

presented here in Table 1:

38 Short Term Insurance Act 1998, Section 70 allows the Minister of Finance to issue additional regulations to regulate the insurance industry. The Minister issued binder regulations in Government Gazette 1078 of 2011/12/ 23.

39 Government Gazette 1078 of 2011/12/23 defines an underwriting manager in section 6.1 as a person that performs one or more of the business of insurance referred to in section $48 \mathrm{~A}(1)$ a-e of the Short Term Insurance Act, for example, to calculate premiums etcetera.

40 Government Gazette 1078 of 2011/12/23 defines a binder agreement as an agreement required to complete the requirements of section $48 \mathrm{~A}$ of the Short Term Insurance Act.

41 Government Gazette 1078 of 2011/12/23 defines enter into in section 6.1 and means any act without the insurer becoming aware of the act until after the act has been performed.

42 Government Gazette 1078 of 2011/12/23 section 6.3(1)g. To settle claims etcetera is referred to as binder functions.

43 Government Gazette 1078 of 2011/12/23 in terms of section 6.4(4) regulates the sharing of profits.

44 Government Gazette 1078 of 2011/12/23 requires a binder agreement to contain the clauses specified in section 6.3. Strangely, the section 6.3 contains no template of a possible formula to calculate profits. The 


\title{
Table 1:An example of how to calculate the profits between the insurer and the underwriting manager
}

\author{
Total premium received per annum $\quad \mathrm{R} 1 \mathrm{~m}$ \\ Less total claims paid per annum R 800000 \\ Less broker commission paid per R125000 \\ annum \\ Less underwriting manager fee (i.e. R50 000 \\ $5 \%$ ) \\ Less insurer's fee (i.e. 3.5\%) \\ R35000 \\ Plus re-insurance commission R100 000 \\ received \\ LesS SASRIA premium paid ${ }^{\text {a }}$ \\ R20000 \\ Less claims incurred but not reported R100 000 \\ (IBNR) \\ Net Profit $(-1+)^{b}$ \\ $-\mathrm{R} 130000$
}

a. SASRIA is a state owned company which covers loss in the event of riots, terrorism and the like. The amount next to SASRIA in the table is not calculated in accordance with the guidelines set by SASRIA and serves only as an example of deductions relevant to the formula explained.

b. Croome 'VAT: Insurance Premiums and Payments from a Policy' 2005 Money Web Tax Breaks 4. It may be necessary to deduct VAT to calculate net profit since net profit payable is subject to VAT. However, irrespective of what the formula should be, any sharing in profits is subject to income tax.

It is possible that the binder agreement will stipulate that only net profit will be shared equally between the insurer and the underwriting manager; not any net profit losses. The formula is not guided by legislation and it' is possible that the insurer and the underwriting manager may agree on additional costs or revenue; for example, excess paid on loss. Any policyholder must pay an excess once a claim is submitted to the insurer. ${ }^{45}$ The excess could either be paid to a third party or is payable to the insurer before settling the policy holder's

calculation of profits remains a logical calculation. See, for example, crop hail loss calculation in Mare, Willemse \& Grove 'Estimating the Maximum Value of Crop Hail Insurance Under Stochastic Yield and Price Risk' 2015 Agrekon 28-44.

45 Ibid for a general explanation of Tax; Candy 'Innovative Insurance' 2005 Money Web Tax Breaks 13. Penalties and or excesses paid by policyholders may also be part of a profitable product; Verhoef 'Innovation and Expansion: Product Innovation and Expansion of Insurance in South Africa. The Case of Sanlam, 1920-1998' 2016 Historia 66-91. This article indicates the policy with which Sanlam began its business in 1910 and discusses the product innovation or development carried out thereafter to increase Sanlam's market share in the insurance industry. 
claim. ${ }^{46}$ The excess paid on a loss is considered additional revenue/ income for the insurer if paid directly to the insurer and can be part of the formula above. The above profit sharing formula is similar to a cell structure business or cell captive business. ${ }^{47}$ The profits can be paid in terms of the binder agreement or in the form of dividends if the underwriting manager has shares in the insurer. Government Gazette 34877 of 23 December 2011 , regulates binder agreements but is not too specific on how profits should be shared i.e. by dividends only.

\section{A Cell Structure}

If an underwriting manager holds shares in an insurer, then in terms of the Insurance Bill the insurer is conducting its business as a cell captive. A cell structure or cell captive business can also employ the above formula in paragraph 2.2.1 as a method to share in the insurer's profits. It is possible that an insurer may require from the underwriting manager a certain amount in fixed shares to comply with the solvency requirements which is proportional to the cell business's income. For example, if the underwriting manager collects $\mathrm{R} 1 \mathrm{~m}$ annual premium, the insurer could require a fixed share purchase of $20 \%$ of the annual premium to comply with solvency requirements. ${ }^{48}$ Whether an insurer could 'outsource' this legislative requirement is unclear, since the Government Gazette 34877 of 23 December 2011, makes no reference to solvency requirements and or the Insurance Bill. Besides the latter uncertainty, from an accounting point of view it would be impossible to share in the profits of the insurer. For example, if the underwriting manager grows $10 \%$ per annum in its business, then the underwriting manager must contribute $20 \%$ of the $10 \%$ growth to the insurer. ${ }^{49}$ To share in the profits of the insurer as stated in Section 1 of the Bill becomes nearly impossible; the underwriting manager pays R200 000 for shares to equal the solvency requirements of a $\mathrm{R} 1 \mathrm{~m}$ annual premium and the following financial year an additional R20 000 etcetera. Before sharing in any profits the underwriting manager would have paid R220 000 to the insurer. If we consider the sharing of profits formula example, it is clear that the net profit is minus R130 000. If the binder agreement makes provision for sharing of profits and losses, this implies

46 If it is a short term policy relevant to vehicles, the policy holder must pay an excess either to the repairer of the vehicle or the insurer.

47 Government Gazette 1078 of 2011/12/23 in terms of section 6.3 and 6.4 Sharing in profits can also imply dividend payments based on shares acquired in the insurer, but is not specified explicitly in section 6.4(4). For this reason the Insurance Bill introduces cell structure terminologies applicable to the Short Term Insurance Act 1998.

48 Business Day (2005-09-07) 8 for a general discussion on the solvency margin as $25 \%$ of the gross premium received.

49 The Insurance Bill in section 1 does not exclude the possibility of a solvency requirement for a specific cell. However, solvency requirements are a requirement for the insurer to comply with in terms of section 28 of the Short Term Insurance Act. This is a legislative requirement for short term insurers only; hence to 'outsource' this requirement in terms of a contract should not be permissible. 
that the underwriting manager is liable for this R130 000 loss and that the manager was obliged to pay R220 000 in capital. Is it possible for an entity with limited resources to comply with these financial requirements? We believe that sharing in solvency requirements is a legislative duty imposed on the insurer alone and cannot be ceded or outsourced to any underwriting manager. In addition, the definition of a cell structure does not contain solvency requirements but we argue that it should not be part of the cell business for the financial reasons explained above. It is possible that the underwriting manager and insurer may agree to share the underwriting loss of R130 000 equally in the binder agreement or any other agreement that relates to the cell structure business. ${ }^{50}$ However, any losses could be covered by a reinsurance treaty or contract between the insurer and a re-insurance company, making the sharing of losses between an insurer and underwriting manager impractical and irrational. ${ }^{51}$

\section{A Cell Structure and a Central Society Compared}

A friendly society cannot issue any shares to any other society, company or individual, making our explanation of a cell structure above irrelevant to our discussion in terms of Section 40(2)c of the Friendly Society Act. Nevertheless, a central society could conclude an agreement with a society to share in the net profits or losses of the society in terms of Section 13(n) which regulates the sharing/disposing of profits subject to the approval of the registrar of friendly societies. The formula relevant to share in profits without any shareholding between a central society and a society could be similar to the formula between an underwriting manager and an insurer discussed earlier. ${ }^{52}$ Nevertheless, Section 39 defines a central society as follows:

(a) Central society means a society which controls two or more affiliated societies liable for payment of contributions (premiums) to its funds. The societies contributing to the funds of a central society shall be deemed to

50 Some insurers conclude a binder agreement and in addition, another agreement pertaining to the payment of losses. The payment of losses could be effected to a third party company, which is part of the insurer's business and may include solvency requirement payments. Once again, to require an underwriting manager to pay for solvency requirements and losses is too stringent, making the sharing of profits nearly impossible. Such agreements which require solvency payments should be interpreted as contra bones mores where only the insurer is required to comply with solvency requirements. See for example, Government Gazette 34715 of 2011/10/28 section 5 of the Gazette and section 29(1)b of the Act; Section 29 refers specifically to short-term insurers and not to underwriting managers. There are different methods to calculate solvency requirements in terms of section 5 of the Gazette relevant to insurers only. See Kerr The Principles of the Law of Contract (2002) 164, 181.

51 See https//www.investopedia.com (accessed 2016-01-05). The insurer cedes a part of its insurance policies' risk to a reinsurer in exchange for a premium. If no claims were made, the reinsurer may refund a portion of the premiums to the insurer, known as a reinsurance commission.

52 See paragraph 2.2.1. 
be its members and the central society shall not admit as members any persons other than its affiliated societies.

Section 1 of the Act defines society members as either natural persons and or affiliated societies; affiliated societies can perform the same functions as illustrated by the relationship between an underwriting manager and the insurer. The relationship between a central society and affiliated society could be regulated by a separate agreement, similar to a binder agreement, explained earlier. In terms of Section 40(3) of the Friendly Society Act, where a society's rule is in conflict with a central society's rule, for all practical purposes the society's rule is subordinate to the central society's rule in order to comply with Section 39 of the Friendly Society Act:

(a) Affiliated society means a society which is under the control of a central society and is bound to contribute to a fund administered by such central society.

It is therefore possible that the central society and affiliated society are entitled to a fee or administration fee for contributing to and or administering the fund, which should be similar to the fee as indicated earlier, relevant to an insurer's fee and underwriting manager's fee for administration purposes. ${ }^{53}$ The administration of the fund entails the distribution of members' benefits to the society's member and or collection of members' contributions/premiums to the fund, etcetera.

\section{Members' Benefits}

The Friendly Society Act regulates members' benefits in Section 2 as objects of the friendly society. Section 2 states that a society can be established for one or more of the following objects or benefits:

(a) Relief of maintenance during minority or ${ }^{54}$

(b) Relief of maintenance during widowhood, sickness and or mental sickness or ${ }^{55}$

(c) Granting annuities or ${ }^{56}$

(d) Sum of money to be paid on birth of a member's child or death of a member or ${ }^{57}$

(e) Sum of money towards funeral expenses or 58

(f) Insurance against fire or other contingencies of the implements of trade or calling of any member or ${ }^{59}$

53 Ibid.

54 Section 2(a).

55 Ibid.

56 Section 2(b).

57 Section 2(d).

58 Section 2(d)iii.

59 Section 2(e). 
(g) Sum of money to be paid when a members leaves his or her employment or $^{60}$

(h) Sum of money to be paid when the member is unemployed or 61

(i) Sum of money to be paid for the advancement of education or training of members or ${ }^{62}$

(j) Any other relief or sum of money as may be directed by the minister in a government gazette. ${ }^{63}$

The above policy or society benefits are regulated by the rules or constitution of the society. The rules may solely regulate a specific benefit payable to the members of a society, or may contain multiple benefits payable to members in the event of a disability or otherwise; for example, a fire which has damaged a member's house and benefits which relate to mental illness and the like. The society and the members are free to agree on any rights and or duties pertaining to the objects/ benefits of the society but these rights and duties should be financially sound. The Act requires that the registrar of friendly societies should only register a society's constitution if the constitution is financially sound or, if, in other words, in accordance with the opinion of an actuary, the rights and duties pertaining to the payment of benefits in return for a monthly premium will not prejudice the society financially. For example, the assumed monthly premiums to be received and assumed liability for payment of benefits would be less than $80 \%$ of the total annual premium. ${ }^{64}$ If the payable benefits exceed $80 \%$ per annum this implies financial prejudice; the annual premiums will be insufficient to continue with the business of insurance. 65

\section{Insurance Bill}

\section{Background to the Department of Treasury's document}

In July 2011, the Treasury issued a document relevant to friendly societies containing new terminologies and concepts as a method to highlight the shortcomings of the current Friendly Society Act. ${ }^{66}$ The Insurance Bill does not repeal the current Long Term Insurance Act nor the Short Term Insurance Act, but includes new proposals on how to regulate the financial industry applicable to insurers; for example, micro

60 Section 2(f).

61 Section $2(\mathrm{~g})$.

62 Section 2(h).

63 Section 2(i).

64 Section 5(4)a.

65 See www.kpmg.com/ZA/en/IssuesAndInsights/ArticlesPublications/Finan cial-Services/Documents/2014 KPMG Insurance Survey.pdf (accessed 201603-01). The annual expenses of any insurer (salaries, telephone etcetera) should not exceed, a general rule, $27 \%$ of the annual gross premium.

66 See www.treasury.gov.za/publications/other/MicroinsuranceRegulatoryFra mework/Policy \% 20Document \% 20Micro \% 20Insurance.pdf (accessed 201601-01); See also Gibson 'The Future of Micro Insurance Regulation in South Africa' 2008 The Professional Accountant 28. 
insurance and or cell structures. ${ }^{67}$ The 2011 document issued by the Treasury distinguishes between different sizes of societies and or stokvels. For example, if a society or stokvel has less than 2500 members, both the friendly society and the stokvel should register as cooperatives in terms of the Co-Operative Act 14 of $2005 .^{68}$ The characteristics of a co-operative fall outside the scope of this article. Needless to say, if a society or stokvel has more than 2500 members and has capital greater than R1.5 million, it will be allowed to register as a micro insurer. On the other hand, if a stokvel consists of a few members then for all practical purposes the stokvel may continue as is without any legislative regulations; such as for example, the Co-Operative Act or Insurance Bill. ${ }^{69}$ Therefore, the same consequences explained earlier, will still be relevant in the future; for example, the stokvel can pay any amount of money/benefit to its members and or can collect any amount of premium from its members. ${ }^{70}$ This type of stokvel can invent or create any form of benefit and or pay any amount of money as a benefit since this type remains unregulated.

\section{What is a Micro Insurer?}

The department of treasury's document mentions the size of a micro insurer (minimum 2500 members) and the amount of capital (R1.5 million) as requirements to register either a stokvel or friendly society as a micro insurer. ${ }^{71}$ On the other hand, the Insurance Bill defines a micro insurer and micro insurance business in Section 1 as follows:

67 See in general Bollen 'Recent Developments with Banking Services in Developing Countries' 2009 Journal of International Banking Law and Regulation 509. The importance of developing micro insurance is simply that it caters for the needs of the poor. The legislation relevant to regulations regarding the poor is known as welfare law or social security law. Social security law regulates, for example, access to basic financial services.

68 Gibson supra n 68 at 29. The author explains that micro insurance can operate without a separate Micro Insurance Act by amending the Long Term Insurance Act and Short Term Insurance Act. The Insurance Bill to a large extent amends these pieces of legislation; however, it is unclear whether a micro insurer registrar will be required, or whether the current short term registrar will see an increase in regulatory duties to oversee the micro insurance industry; Business Day (2014-07-29) 2.

69 See in general Macchiavello 'Securitisation in Micro Finance and Global Financial Crisis: Innovation or Trojan Horse?' 2010 Journal of International Banking and Regulation 109. This article illustrates the increases in demand for micro finance or access to micro finance/credit.

70 See www.treasury.gov.za/publications/other/MicroinsuranceRegulatoryFra mework/Policy \% 20Document \% 20Micro \% 20Insurance.pdf (accessed 201601-01).

71 See in general Chummum "Weather Micro-insurance and the Support of Low Income and Vulnerable Communities: The Case of the Island of Mauritius' 2014 Journal of Africa Growth Institute 9; D Millard \& L Mpedi supra n 1; See also www.treasury.gov.za/publications/other/Microinsurance RegulatoryFramework/Policy \% 20Document \% 20Micro \% 20Insurance.pdf (accessed 2016-01-01). 
(a) Micro-insurer means a micro insurer licensed to conduct only micro insurance business;

(b) Micro insurance business means insurance business

(a) Conducted in respect of any of the following classes and sub-classes of insurance business set out in schedule 2

(1) Non-life insurance business, personal lines in

(aa) classes 1-3,11 and 14 and

(bb) class 10 but only to the extent that the liability directly relates to the classes referred to in item (aa) and

(2) Life insurance business, class 1 to 3 and

(b) In the case of non-life insurance business, in respect of which the aggregate value of the insurance obligations under an insurance policy do not exceed the maximum amounts prescribed

(c) In the case of life insurance business, in respect of which the aggregate value of the insurance obligations relating to each insured under an insurance policy do not exceed the maximum amounts prescribed and

(d) In respect of which all policies comply with the policy holder protection rules prescribed by the registrar under the long term insurance act and short term insurance act.

In (d) above long term and short term insurers and or their underwriting managers must comply with policy holder protection rules. The definition of a short term insurer in Section 1 of the Short Term Insurance Act is very simple; it states an insurer is registered as such in terms of the Short Term Insurance Act and exactly the same definition applies to a long term insurer in the terms of the Long Term Insurance Act. We therefore foresee that the Long Term Insurance Act and or the Short Term Insurance Act will probably contain a definition which states that a micro insurer is an insurer registered in terms of the Short Term Act if the micro insurer sells products relevant to this Act and vice versa for the Long Term Act to comply with policy holder protection rules. ${ }^{72}$ The Treasury Department proposed a separate Micro Insurance Act relevant only to micro insurers but it is clear that this proposal is not being adopted. It is unclear whether the current registrar of short term insurance or the long term insurance registrar will oversee the regulatory activities of the micro insurance industry or whether a separate micro insurer registrar will exist. ${ }^{73}$ The definition of a micro insurer makes no mention of relevant business schemes similar to the relationship between a friendly society and a central society. Irrespective of the latter sentence, it is possible that the short term (and or long term) registrar may, for example, issue business scheme regulations in terms of Section 70 of the Short Term Insurance Act, similar to binder schemes between

72 See in general Gibson supra n 68 at 28.

73 See www.treasury.gov.za/publications/other/MicroinsuranceRegulatoryFra mework/Policy \% 20Document \% 20Micro \% 20Insurance.pdf (accessed 201601-01). 
an insurer and underwriting manager. ${ }^{74}$ Although no mention is made of business schemes, the definition of a premium, as discussed in the paragraphs below, indicates the possibility of business schemes being entered into between micro insurers and other companies.

\section{Business Carried on Under a Scheme or Binder Agreement}

The Binder regulations make provision for a company that is not registered as an insurer to act as if it is the insurer, as the result of a binder agreement. ${ }^{75}$ The company is known as an underwriting manager. The latter terminology and the definition thereof are not part of our discussion in this article; however, in brief: an underwriting manager may share in the profits of the insurer. We indicated earlier that this formula is also relevant in the relationship between a central friendly society and a friendly society. Whether this formula is relevant to a micro insurer is unclear. ${ }^{76}$ The Insurance Bill refers solely to an insurer in Section 1. The document issued by the Treasury Department proposes a similar binder agreement for the micro insurance industry as presently found between insurers and underwriting managers; for example, a cell structure or a cell captive scheme. ${ }^{77}$ Should the term 'insurer' include a micro insurer then it would be possible for a registered micro insurer to conclude an agreement with a company who is not registered as a micro insurer to enable the company to share in the profits of the said micro insurer. This company may therefore calculate premiums in return for policy benefits, settle claims, reject claims, determine the policy wording on behalf of the micro insurer. ${ }^{78}$ The following paragraph focuses the discussion on premiums in return for policy benefits.

74 See for example, Government Gazette 1078 of 2011/12/23, which regulates the agreement or binder agreement between an underwriting manager and the insurer.

75 See in general Macchiavello supra $\mathrm{n} 71$ at 111

$76 \mathrm{Ibid}$. On page 111, the author describes similar schemes or vehicles to avoid balance sheet disclosure since there are two separate companies doing business with each other. The author also explains different types of schemes; for example, direct securitisation. These types of schemes are irrelevant to our discussion; nevertheless they demonstrate the importance of sharing risks between companies, and so forth.

77 Directive 151 issued by the Financial Services Board on the 1 April 2010, which refers just to a registered short term insurer and makes it clear that a micro insurer is not a registered short term insurer; See in general Gibson supra $\mathrm{n}$ 68; see www.treasury.gov.za/publications/other/Microinsurance RegulatoryFramework/Policy \% 20Document \% 20Micro \% 20Insurance.pdf (accessed 2016-01-01).

78 See for example, Government Gazette 1078 of 2011/12/23, which refers to binder functions i.e. calculate premiums, policy wording and the like in section 6.3(1)g. 


\section{Premium in Return for Policy Benefits}

Premiums are not defined in the Friendly Society Act. However, the Insurance Bill defines a premium in Section 1 which reads as follows:

Premium means any direct or indirect, or partially or fully subsidised payment of any consideration.

This definition is very technical and extremely difficult to understand from a legal or accounting point of view. To explain the definition it is important to make use of the following example presented in below in table format (Table 2) to identify the differences between premiums and subsidised premiums. ${ }^{79}$ Premium or gross premium includes a risk premium since the policy holder pays a gross premium to the insurer in exchange for policy benefits. However, the risk premium in this regard deals exclusively with accountancy/actuarial principles. ${ }^{80}$ The example below is the gross written premium which, less broker fees, less value added products, equals risk premium. Broker fees are not equal to broker commission, while value added products are products underwritten by other insurance companies who are willing to accept a lesser premium in exchange for policy benefits as a method to price premiums more competitively in the market. ${ }^{81}$ The names of these insurance companies are not disclosed to the policy holder since the policy holder is not transacting directly with the other companies. ${ }^{82}$ If the policy holder submits a claim, the insurer who sold the gross written premium product will deal directly with the policy holder to settle his or her claim. Afterwards, the insurer will submit a claim against the other insurer and

79 The Short Term Insurance Act in section 1 defines only a premium. A premium is a consideration given in return for an undertaking to provide policy benefits.

80 See in general Forough, I Jones \& Dardis 'Investment Guarantees in the South African Life Insurance Industry' 2003 South African Actuarial Journal 29-75. On page 32, the researcher refers to 'risk premium' without giving a suitable definition. It may be that this phrase is part of general terminology in the financial sector and that the same rationale or explanation may be used in the short term industry to explain risk premium as a premium without any value added products, etcetera.

81 The Short Term Insurance Act in section 8(5) regulates broker fees; See in general Schulze 'The Mode of Payment of Insurance Premiums: Different Methods Compared' 2011 SA Merc 64-81. On page 67, the researcher provides different scenarios of premium payments i.e. to different intermediaries/insurers.

82 See in general Macchiavello supra $n$ 71. This article uses a general explanation of different schemes, and the author is silent on whether all the parties should be disclosed or not; Verhoef supra n 47. On page 69 the researcher states clearly that the literature available to support current industry developments is scanty. On page 73 the researcher lists industry firsts in product innovation. For this reason value added products are also used to limit the risk for the insurer by outsourcing those policy benefits to another insurer in return for a premium. 
the latter will settle or pay the claim. The above can be illustrated by the following example: ${ }^{83}$

\title{
Table 2:Identifying the differences between premiums and subsidised premiums
}

\author{
Gross written premium paid by R600 \\ policyholder \\ Less broker fee paid to the broker by R50 \\ the insurer \\ Less value added product premium R60 \\ paid by the insurer to the other insurer \\ Risk premium received by the insurer $\mathrm{R} 490$ \\ Gross premium percentage of risk $82 \%$ \\ premium
}

The insurer who insures the motor vehicle will be receiving a risk premium of R490 and the other insurance company a fully subsidised premium of R60.

The concept of the direct or indirect payment of any premium is also highly technical and we were unable to find any law literature dealing with these types of payments. To illustrate these from a legal point of view, direct payment is simply payment made directly into the bank account of an insurer in exchange for policy benefits. Indirect payment deals exclusively with Section 45 of the Short Term Insurance Act. In terms of this Section, it is possible for an insurer to mandate an underwriting manager to collect premiums on behalf of the insurer and to keep the premiums collected for a maximum of 15 days. ${ }^{84}$ Whether a company who acts on behalf of the micro insurer is able to use Section 45 is unclear. ${ }^{85}$ The above example of a subsidised premium payment is not set in stone and varies from one insurer to another; direct or indirect payments give an indication of the intention of the legislature to introduce business schemes to the micro insurance industry. If not, then it simply implies that similar relationships, as found between a friendly society and the central society, will not continue in the new Insurance Bill.

83 See in general Verhoef supra $\mathrm{n}$ 47. On page 83 the researcher asserts Sanlam's ability to be flexible in product development. This footnote is not specific since no literature could be found.

84 The Short Term Insurance Act 1998 in section 45(a) and Directive 145 issued on 16 August 2011 in section 5.12 requires a time period of 15 days. This Directive was issued by the Financial Services Board.

85 Directive 145 stipulates that just those insurers who authorise underwriting managers may collect premiums on their behalf. 


\title{
42 Financial Consequences of a Risk Premium
}

This is an ideal opportunity for the legislature to distinguish between premium, gross written premium and risk premium, since all calculations to calculate the profits or losses for an underwriting manager depend generally on the total premiums received per annum. If the underwriting manager who acts on behalf of the insurer participates in the profits of the insurer, the following serves as an example how to share in the profits based on a risk premium per annum.

\section{Table 3:An example of percentage of payments of policy benefits in relation to risk premium}

\author{
Total risk premium received per $\mathrm{R} 1 \mathrm{~m}$ \\ annum \\ Less total claims paid per annum R 800000 \\ Loss ratio (or payments of policy $80 \%$ \\ benefits ratio in relation to the risk \\ premium $)^{\text {a }}$
}

a. Jacobs \&Wagener 'The Importance of Insurer's Commercial Interest in the Removal of Discriminatory Gender Rating Variables in Calculating Insurance Premiums and Benefits: A Comparative Legal Analysis' 2012 SA Merc 233-251. The researchers focus on the loss ratio for men compared to women as a reason why some insurance companies prefer women as policyholders. The specific loss ratio is not provided - men younger than 22 are 25 times more likely to cause an accident.

If we use the above, and we employ our explanation of a gross written premium which includes broker fees and or value added products, then the following scenario, presented in Table 4, is possible:

\section{Table 4:An example of percentage of payments of policy benefits in relation to gross written premium} Total gross written premium received
per annum

Less total claims paid per annum

Loss ratio (or payments of policy $67 \%$
$\mathrm{R} 1.2 \mathrm{~m}$ ( $1 \mathrm{~m}$ is plus minus $82 \%$ of $\mathrm{R} 1.2 \mathrm{~m}$ - see first table of this paragraph above)

R 800000

benefits ratio) 
The difference in profit sharing, comparing $67 \%$ with $80 \%$, is significant. For this reason we propose that the Insurance Bill should distinctly stipulate the difference between a risk and gross premium to understand the sharing of profits more unambiguously from a legal point of view. The above difference may well be confusing to say the least and it is possible that an insurer may make use of the above to prejudice a company who acts as an underwriting manager. A practical example might take the form of the following: the company and the insurer agree on a sliding scale to share in the annual underwriting profits; for example, $10 \%$ of the profits if the loss ratio is less than $70 \%$ and no sharing of profits if the loss ratio is more than $70 \%$. If premium is to be interpreted as risk premium then it would be extremely difficult for the company to share in the insurer's profits. ${ }^{86}$

\section{Members' Benefits}

In terms of the Treasury Department's proposals for micro-insurance, the policy benefits should be limited to a maximum of R50 000 for life products and or other long term insurance products and a maximum of R100 000 for asset products and or other short term insurance products per single event. ${ }^{87}$ However, if a family of three died in a motor vehicle accident it is permissible to pay a combined amount of R150 000 per single event, even although the maximum member benefit is R50 000 (page 8). Member benefits or policy benefits cannot exist for longer than 12 months. ${ }^{88}$ This implies that if a person insures an asset or motor vehicle, the policy will expire after 12 months and is only renewable on request of the policy holder. ${ }^{89}$ The types of policy benefits are divided into different classes in the Insurance Bill; for example, classes 1-3 regulate long term insurance products whereas classes 11, 14 and 10 relate to short term insurance products. ${ }^{90}$ These products will provide for the following benefits: Class 1 specifies ten different types of insurance policies (life policy, death policy, health policy, disability policy, group life policy, group health policy, group health lump sum policy, group

86 It should be remembered that any value added product pays to the underwriting manager an equal amount of money paid by the underwriting manager to the policy holder. For this reason, risk premium calculation is not the preferred method to calculate the sharing of profits.

87 See www.treasury.gov.za/publications/other/MicroinsuranceRegulatoryFra mework/Policy \% 20Document \% 20Micro \% 20Insurance.pdf (accessed 201601-01).

88 Business Day (2010-12-29) 2. In this article, reference is made to R50 000 benefit. It should be kept in mind that the R50 000 in future value terms (6 years later where inflation is approximately 5\%) is R50 $000 \times 1.34$ which equals R67 000. The Insurance Bill makes no provision for future value and the maximum payable benefits must be calculated in terms of future value as to keep up with inflation.

89 See www.treasury.gov.za/publications/other/MicroinsuranceRegulatoryFra mework/Policy \% 20Document \% 20Micro \% 20Insurance.pdf (accessed 201601-01).

90 See Insurance Bill Schedule 2, classes 1-18. 
disability policy and group disability lump sum policy); Class 2 specifies two different type of policies (credit life and credit group policy); Class 3 specifies two different type of policies (group funeral policy and funeral policy); Class 10 specifies 14 different types of insurance policies (director liability policy, employer liability policy, fidelity policy, product liability policy, professional indemnity policy, aviation policy, engineering policy, marine policy, motor policy, railway policy, transport policy etcetera); Class 11 specifies just consumer credit policies and Class 14 , accident and health policies. What is interesting to note is that the Treasury proposed micro re-insurance benefits where other micro insurers acts as re-insurers (page 8) but that in the Insurance Bill, reinsurance products fall under Class 17 and are specifically excluded from the definition of the business of a micro insurer. ${ }^{91}$

\section{Conclusion}

The Insurance Bill introduces new terminologies and new insurance concepts to the South African financial/corporate landscape. ${ }^{92}$ The Friendly Society Act will be replaced by the Insurance Bill when it becomes law, so as to regulate society products as micro insurance products. ${ }^{93}$ The requirements to register a society and or to register a stokvel as a society will continue to be relevant when the Insurance Bill is promulgated. ${ }^{94}$ It seems that a stokvel as a business entity will continue to exist if the requirements for a micro insurer are not being met, for example, less than 2500 members and capital less than R1.5 million. It is therefore possible that a stokvel will remain unregulated in the South African corporate landscape, ${ }^{95}$ suggesting that such an entity can create any form or type of product with no maximum payable benefits as long as it has less than 2500 members and or less than R1,5 million capital. Currently, the Friendly Society Act allows for different types of products payable up to a maximum amount of R7500. When the Insurance Bill becomes law the micro insurer will be allowed to pay up to R50 000 benefits for products associated with the Long Term Insurance Act and R100 000 for products associated with the Short Term Insurance Act. Whether a central society as a business scheme will continue when the Bill becomes law remains unclear. This is strange, since similar business schemes are relevant to either the Long Term Insurance Act or Short Term Insurance Act; for example, the relationship between underwriting managers and insurers.

\footnotetext{
91 See Insurance Bill Schedule 2, class 17.

92 See paragraph 2.2.1 and 2.2.2.

93 See paragraph 2.3 and 5.

94 See paragraph 2.1.1 and 3.1.

95 See paragraph 3.1.
} 